\title{
New Postcranial Hominin Fossils from the Central Narmada Valley, India
}

\author{
Anek R. Sankhyan ${ }^{1 *}$, Giani L. Badam ${ }^{2}$, Laxmi N. Dewangan ${ }^{3}$, Sheuli Chakraborty ${ }^{3}$, \\ Shashi Prabha ${ }^{3}$, Suvendu Kundu ${ }^{3}$, Rana Chakravarty ${ }^{3}$ \\ ${ }^{1}$ Palaeo Research Society, Ghumarwin (H.P.), India \\ ${ }^{2}$ Anthropological Survey of India (Indian Museum Campus), Kolkata, India \\ ${ }^{3}$ Hermes Paras, Kalyani Nagar, Pune, India \\ Email: arsankhyan@gmail.com
}

Received May $12^{\text {th }}, 2012$; revised June $13^{\text {th }}, 2012$; accepted June $24^{\text {th }}, 2012$

\begin{abstract}
Hathnora in Central Narmada valley (Madhya Pradesh) has earlier yielded a partial skullcap, and two clavicles and a $9^{\text {th }}$ rib of Middle Pleistocene hominins. Recent explorations have brought to light two more hominin fossils - a humerus and a femur from a new locality, Netankheri. The femur is derived from the Middle Pleistocene stratigraphic horizon as the Hathnora skullcap, and shares similar "archaic" mosaic morphology of Homo heidelbergensis, also attested by new bio-stratigraphic and Palaeolithic data. The humerus is derived from the pre-YTA ( $75 \mathrm{Kya})$ Upper Pleistocene strata in association with unique fossilized bone artifacts and documents the early emergence of anatomically modern Homo sapiens in South Asia.
\end{abstract}

Keywords: Pleistocene; Hominins; Narmada Valley; Humerus; Femur; H. erectus; H. sapiens; $H$. heidelbergensis

\section{Introduction}

Since 1830s the Central Narmada Valley in Madhya Pradesh has yielded innumerable Palaeolithic artefacts and Pleistocene mammalian fauna. 150 years later, the year 1984 saw a discovery of Middle Pleistocene hominin partial cranium (Sonakia, 1984), followed later by the discovery of two clavicles and a partial left $9^{\text {th }}$ rib (Sankhyan, 1997a, 1997b, 2005) from a layer just above near the same site, Hathnora. These findings brought Central Narmada valley to the forefront of human evolution in South Asia and generated considerable debate on the taxonomic status of Narmada hominin. The partial cranium received greater attention from Lumley \& Sonakia (1985), who conceived it as of an "evolved" Homo erectus, the stand more recently continued by another French scholar, Mallasse (2009). This was followed by another study by Kennedy et al. (1991), who highlighted several advanced traits and therefore referred it, to an "archaic" Homo sapiens. Several scholars viewed the cranium in the same manner on different grounds (Badam et al., 1986; Sankhyan, 1999, 2006; Kennedy, 2000; Cameron, 2004). Of late, the terms "evolved" Homo erectus "archaic" or "archaic" Homo sapiens cladistically received different connotations, and therefore, Narmada partial cranium was referred to a much wider Old World species, Homo heidelbergensis (Kennedy, 2007; Athreya, 2007; Sankhyan, 2010).

Initially, the two clavicles and the rib fossils were thought to have been derived from the same cranially known Middle Pleistocene hominin on grounds of stratigraphic proximity and inferred female sex and similar estimated age at death (Sankhyan, 1999). But, they remained enigmatic mismatch (Pearson, 2000) to the cranium, and therefore were ignored by notable scholars

"Corresponding author. like Kennedy (2000) in discussion on hominin evolution in Narmada valley. Of course, they do not corroborate in the estimated body dimensions of a single hominin, and appeared morphologically distinct (Sankhyan, 2007), and therefore open up a possibility of a hitherto unknown Pygmy-sized species or archaic population in Narmada valley (Sankhyan \& Rao, 2007; Van Heteren \& Sankhyan, 2009), strengthened by a recent study (Sankhyan, 2010).

\section{The New Findings}

The present study reports two new hominin fossils from the Central Narmada valley described here. They include a partial left humeral diaphysis NTK-F-02-07 (Figure 1) and a distal shaft fragment of the left femur NTK-F-07-05 (Figure 2), housed at Kolkata in the Palaeoanthropology Repository of the Anthropological Survey of India. These were derived from two different stratigraphic levels of a new fossil locality, Netankheri, located about $3 \mathrm{~km}$ upstream of Hathnora, along the northern bank of River Narmada (Figures 3 and 4).

\section{The Humerus}

The specimen is fully mineralized and exhibits post-fossilization linear cracks, especially on the medial border. The preserved portion below the radial sulcus (spiral groove) unto the upper margin of the olecranon fossa measures $84 \mathrm{~mm}$. The specimen is cylindrical proximally, widening and turning prismatic distally. It is bounded by three borders and three surfaces, and shows a medial bend on the posterior surface, where the brachialis narrows upward and widens downward. Distally, the posterior surface is flattened and covered by the lateral and medial heads of the triceps brachia that give rise to part of the 


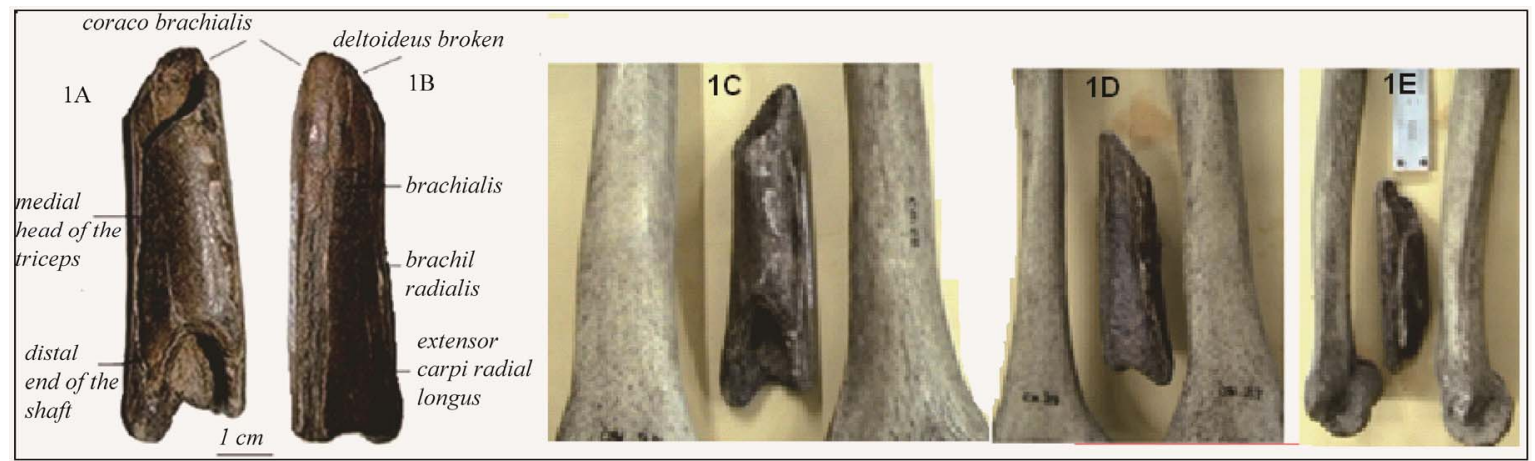

Figure 1.

Netankheri left humerus fossil: (1A) (anterior); (1B) (posterior); (1C), (1D), (1E) comparisons in different views with two modern chaurite.
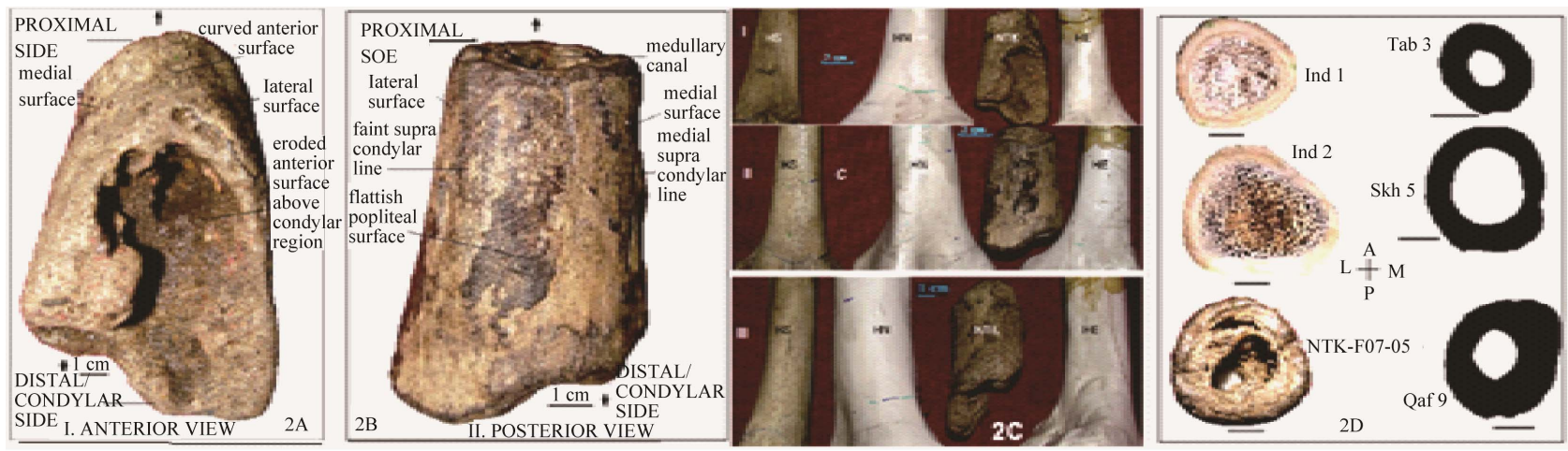

Figure 2.

Netankheri distal femur fossil (2A) (anterior); (2B) (posterior) and comparison with modern; Neanderthal and Homo erectus femora (2C) and in cross sections (2D).

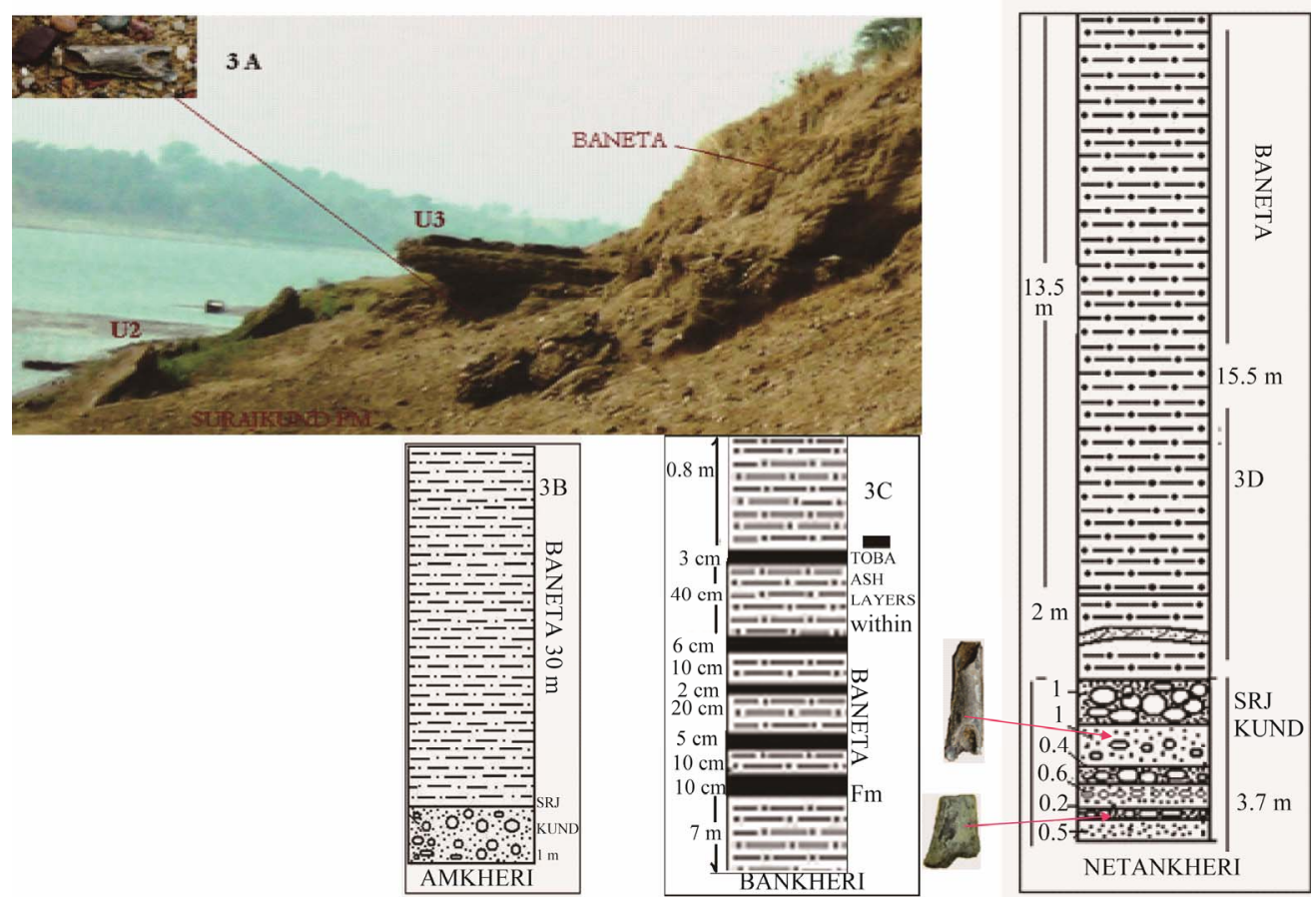

Figure 3.

The humerus site (3A) and the stratigraphic position (3B) at U3 boulder conglomerate at Netankheri, right bank of Narmada River. Lithosection at Bankheri (3C) on the left bank of Narmada River near Babai containing the YTA layers in the Baneta Fm (3D). 


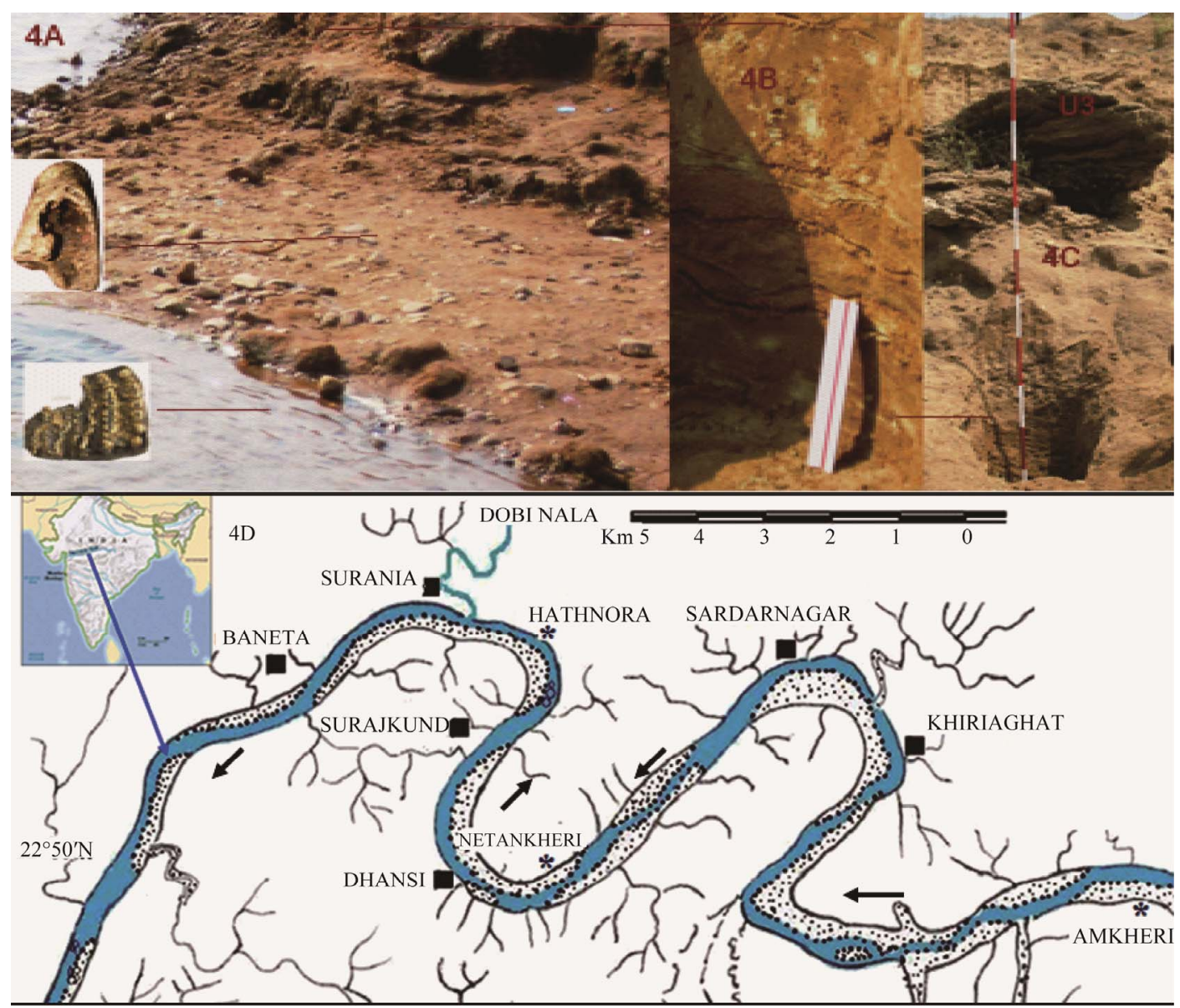

Figure 4.

The site (4A) and stratigraphic position ((4B) \& (4C)) of the Netankheri femur fossil in the U1 boulder conglomerate bed and the area map (4D) in Central Narmada Valley.

brachialis. The anterior border is smooth and rounded. The lateral border is sharp crest like and rough distally; upraises obliquely medial ward with a broad shallow oblique depression in the centre. The medial border is broken at its centre.

\section{Comparative Assessment}

It is relevant to know whether the NTK humerus is of an archaic hominin or of modern human. A recent study (Todd \& Churchill, 2006) shows that archaic vs modern human differentiation could be established by the proximal end of ulna, and not by the distal humerus. Nevertheless, fossilization and stout morphology may indicate a "late archaic" character of the NTK fossil humerus. Its $84 \mathrm{~mm}$ preserved fragment yields an estimated total length of $240 \mathrm{~mm}$ (Table 1), which is even shorter than the mean length of five Chaurite humeri $(291.4 \pm 13.43$ $\mathrm{mm})$ as well as from a larger sample of 33 mixed mainland Indian including Chaurite $(284.74 \pm 27.19 \mathrm{~mm})$. Interestingly, the NTK and Chaurite Nicobari population is shorter and stockier in the available comparative sample which includes Omo Kibish and Cro-Magnon 1 (Carretero, 2009; Bermudez de Castro et al., 2012, personal communication).

Thus, coupled with the earlier findings of two clavicles and a rib, the NTK humerus suggests that the Central Narmada Valley was continuously occupied by "short and stocky" early to late archaic or early modern Homo sapiens populations during Middle to Late Pleistocene of South Asia, and it is not unlikely they included the ancestors of similar short-bodied ancient Indians/South Asians including the Andaman Pygmy.

\section{The Femur}

The specimen (Figures 2(A) and (B)) is fully mineralized, 81 $\mathrm{mm}$ distal-most shaft portion of the left femur, detached from the condyles. The popliteal surface is well preserved while articular surface of the patella intercondylar fossa is eroded. Direct comparisons with similar sized mammalian femurs ruled out its non-hominin identity, and the specimen shows a typical cylindrical shape of the hominin femur body or corpus femoris, which broadens and flattens distally near the condylar region forming a distinct triangular popliteal surface on the posterior aspect. When the femur is held with its body perpendicular, its lateral surface looks larger and rounded compared to the relatively narrow and slightly pinched medial surface above the condyles, which flares more medially backward. This demonstrates that it is a left femur.

\section{Comparative Assessment}

Comparative morphometrics of femur specimens are presented in Table 1. Although limited by preservation, the most 
Table 1.

Metric comparison of the Narmada fossilized humerus and femur with modern mainland Indians and Chaurite Nicobari of Andaman-Nicobar Islands, and other Pleistocene hominins. M-L = medio-lateral diameter or lateral pillar thickness; A-P = antero-posterior diameter or middle pillar thickness; all measurements in millimeter.

\begin{tabular}{|c|c|c|c|c|c|}
\hline \multicolumn{6}{|c|}{ Humerus Mid-Shaft Measurement } \\
\hline Skeletal Population & $\mathrm{N} \&$ Value & M-L/LPT & A-P/MPT & GIRTH & LENGTH \\
\hline \multirow[t]{2}{*}{ Netankheri Fossil (NTK-F-02-07) } & 1 & 18.3 & 18.7 & 67.5 & $84=240^{\mathrm{es}}$ \\
\hline & 33 & 16.02 & 16.56 & 60.02 & 284.70 \\
\hline \multirow[t]{3}{*}{ Mainland Indians + Chaurite Islanders } & SD & 2.65 & 2.43 & 5.82 & 24.19 \\
\hline & SE & 0.46 & 0.42 & 1.01 & 4.21 \\
\hline & 5 & 19.21 & 19.08 & 65.95 & 291.4 \\
\hline \multirow[t]{2}{*}{ Chaurite Islanders } & SD & 3.15 & 1.20 & 4.75 & 13.43 \\
\hline & SE & 1.41 & 0.54 & 2.46 & 6.00 \\
\hline KNM-WT $15000 \mathrm{~F}$ & 1 & 17.3 & 11.8 & & \\
\hline Gombore IB-7594 & 1 & 15.6 & 11.61 & & \\
\hline ATD6-148 & 1 & 14.0 & 7.0 & & \\
\hline BOD-VP-1/2b & 1 & 18.0 & 9.0 & & \\
\hline Kabwe & 1 & 18.4 & 11.9 & & \\
\hline Skhul IV & 1 & 18.6 & 14.2 & & \\
\hline Omo Kibish I-r (KHS-1-30) & 1 & 19.9 & 11.5 & & \\
\hline Omo Kibish I-1 (KHS-1-31) & 1 & 20.6 & 12.0 & & \\
\hline Cro-Magnon 1 & 1 & 20.7 & 14.0 & & \\
\hline Dolní Věstonice & 4 & $16.8 \pm 1.7$ & $9.1 \pm 2.8$ & & \\
\hline Sima de los Huesos & $6 / 9$ & $15.7 \pm 2.0$ & $8.6 \pm 1.3$ & & \\
\hline Neandertals & $21 / 23$ & $15 \pm 2.2$ & $7.7 \pm 1.8$ & & \\
\hline \multicolumn{6}{|c|}{ Femur Distal Mid-Shaft Measurement } \\
\hline NTK-F-07-05 (L) & 1 & 44.85 & 38.05 & 125.5 & \\
\hline Neanderthal $(R)^{1}$ & 1 & 47.3 & 40.7 & 133.5 & \\
\hline Homo erectus (L) (Java) ${ }^{1}$ & 1 & 37.65 & 34.15 & 114.5 & \\
\hline Homo erectus (Tautavel) $)^{2}$ & 1 & 36.9 & 32.55 & - & \\
\hline \multirow{3}{*}{$\begin{array}{l}\text { Modern Indians } \\
\text { (Homo sapiens) }^{3}\end{array}$} & 18 & 34.87 & 27.68 & 102.85 & \\
\hline & SD & 34.87 & 28.11 & 104.65 & \\
\hline & SE & 3.643 & 2.93 & 10.095 & \\
\hline
\end{tabular}

*Estimated, ${ }^{1}$ Measurements on replicas; ${ }^{2}$ On original at Tautavel, France taken in July 2009, access courtesy Professor Henry de Lumley; and ${ }^{3}$ On original in Anthropological Survey of India Palaeoanthropology Laboratory, Kolkata.

notable feature of the NTK femur is its inconspicuous medial and lateral lips resulting in a sub-circular/ovoid shape of the diaphysis in cross section (Figure 2(D)). This is in contrast to the modern human femora, where the two lips emerge into prominent ridges, the linea aspera, which result in a posterior pilaster or flatness. In this respect, the NTK femur is comparable to the robust and rounded femur of the Neanderthal man which lacks the pilaster (Figure 2(C)). Direct comparison with the "late archaic" hominins (Trinkaus, 2007; Trinkaus \& Ruff, 1999; Churchill, 2007; Weaver, 2009), e.g., Tabun 3, Qafze 9 and Skhul 5 was not possible, their cross sections (Figure 2(D)) look apparently similar. Nevertheless, striking metric similarity is with the Neanderthal than Java Homo erectus (Table 1).

\section{The Litho-Stratigraphy at Netankheri}

The two specimens were derived from two different strati- graphic levels exposed near the village Netankheri, located $\left(22^{\circ} 50^{\prime} 25^{\prime \prime} \mathrm{N}, 77^{\circ} 53^{\prime} 6^{\prime \prime} \mathrm{E}\right)$ along the northern bank of the eastwest flowing River Narmada (Figure 3(A)), three kilometers east upstream from Hathnora, $25 \mathrm{~km}$ east of Shahganj. The Netankheri Quaternary litho-stratigraphic section (Figure 3(C)) is $19.2 \mathrm{~m}$ thick; its $3.7 \mathrm{~m}$ lower part is attributed to the Middle Pleistocene Surajkund Formation and the upper to the Upper Pleistocene Baneta Formation (Tiwari \& Bhai, 1997). Like Hathnora (Figure 3(B)), the Surajkund Formation at Netankheri is comprised of three distinct cemented pebble conglomerate beds (Khan \& Sonakia, 1992), denoted as $\mathrm{U}^{1}, \mathrm{U}^{2} \& \mathrm{U}^{3}$ with Inter-layers of yellow sands. A striking feature here is that the U2/U3 units of the Surajkund Fm cemented gravel beds are collapsed and spread as a gravely sand bar for a longer distance by the recent neotectonic anticlines and synclines, besides erosional and re-depositional activities of River Narmada. The collapsed segment contains the fragments of Vndhyan sand- 
stone, and other volcanic materials, like chert, jasper, agate, etc. derived from the Satpura Hills. The lower portion of the Surajkund Fm has sequences of yellowish brown coarse sand and pebbles, and the cemented gravel. The Baneta overlays disconformably as fine brown calcareous clayey silt with grey sand lenses, and thick brown siltyclay.

\section{The Associated Palaeontological \& Archaeological Findings}

The $\mathrm{U}^{1}$ yielded a heavy duty Acheulian pick and a few handaxes at Netankheri, but remarkably over hundred refined heavy duty large Acheulian handaxes, picks, cleavers and chopping tools were recovered in situ at Hathnora. At Netankheri the femur discovered at the $\mathrm{U}^{1}$ level of the Surajkund formation was associated with heavy duty Acheulian implements and a molar fragment of Stegodon insignis ganesa.

The $\mathrm{U}^{1}$ level at Hathnora however yielded a richer assemblage of complete crania and mandibles of Equus namadicus, Elephas namadicus, Bos namadicus, Bubalis palaeindicus and Hexaprotodon namadicus (Sankhyan, 2010). One complete mandible of Equus namadicus was excavated in shallow waters with an Acheulian tool embedded in the conglomerate matrix that filled the mandibular ramii. This is a direct evidence of the contemporaneity of the fauna and the cultural artifacts. The fauna from the $\mathrm{U}^{1}$ level indicate a later Middle Pleistocene age (Sankhyan, 2010; Badam \& Sankhyan, 2009) to the hominin skullcap as well as femur.

In addition, the Neanderthal-like archaic robust morphology of the NTK femur is in concordance with the robust archaic mosaic morphology of the Hathnora partial cranium; the rich mega mammalian fossils as well as heavy duty Acheulian implements recovered from this level (Sankhyan, 2010) also go in line with this inference. Therefore, the Neanderthal-like femur may best be regarded as Homo heidelbergensis since Hathnora calvaria are also better identified with Homo heidelbergensis in recent years.

The NTK humerus derived from the $\mathrm{U}^{2} / \mathrm{U}^{3}$ interface (Figure 3(D)) was found in association with typical Upper Palaeolithic implements as well as the fossilized bone implements; an isolated dentition of Equus hemionus khur was also found at this level. The $\mathrm{U}^{1} / \mathrm{U}^{2}$ interface at Hathnora has yielded two hominin clavicles and a rib of a Pygmy-sized short and stocky hominin (Sankhyan, 1997, 2005). We recently excavated several lightduty Late Acheulian and Middle Palaeolithic implements from this level, (Sankhyan, 2010). Earlier workers (Badam et al., 1986; De Lumley \& Sonakia, 1985) also reported similar artifacts from this stratigraphic level and thought these associated with the calvaria. Now, it is clear that they were likely the handiwork of the Pygmy-sized short and stocky hominin (Sankhyan, 2010).

\section{The Chronology of the Findings}

An electron spin resonance (ESR) date of $>236$ Kya (Cameron et al., 2004) is concordant with the biostratigraphic and cultural findings, though more recent attempts based on linear Uranium uptakes show a wider range 40 to 280 Kya (Patnaik, et al., 2009). Probably, the Hathnora calvaria and the Netankheri femur may probably be of $\sim 250$ Kya old, whereas, Hathnora clavicles and the rib specimen could be younger to $200 \mathrm{Kya}$ in consideration of the totality of faunal and archaeological evidences.
As the humerus specimen was discovered from the collapsed $\mathrm{U}^{2} / \mathrm{U}^{3}$ interface (Figure 2(A)) of the Surajkund Formation, below the Baneta Formation stratigraphic boundary, it is older than the YTA date of $\sim 75$ Kya (Rose and Chesner, 1990; Chesner, 1991) since so far only the Baneta and Hirdepur formations of the Central Narmada Valley are known to contain the Youngest Toba Ash layers (Acharyya \& Basu, 1993; Westgate et al., 1998; Ganjoo et al., 1996).

\section{Discussion \& Conclusion}

Above observations indicate presence of two types of archaic hominins in Narmada valley during Middle to Late Pleistocene times. The "large-bodied" species was wide spread during Middle Pleistocene at lower Surajkund at $U^{1}$ stratigraphic level and hunted mega mammals with typical large-sized Acheulian implements. The "short and stocky" archaic hominins appeared at upper Surajkund level during later Middle Pleistocene time and hunted relatively small game animals using Late Acheulian and Middle Palaeolithic technology. The Netankheri humerus provides evidence for an adaptive continuity of the "short and stocky" hominins during Upper Pleistocene, and they likely formed the ancestral substratum for the later short-bodied populations of South Asia including the Pygmy.

Thus, the "short and stocky" mode 3 archaic hominins may have been but an early (Pre-Toba) "African import" to South Asia thought via Arabian Peninsula (Petraglia, 2007; Petraglia \& Alsharekh, 2003; James \& Petraglia, 2005). They might have survived the "Volcanic Winter" (Ambrose, 1998; Oppenheimer, 2002, 2003) due to unique cultural adaptations (such as bonetool technology), which could have facilitated rapid attainment of anatomical modernity as well (Sankhyan, 2010). The recent mtDNA $M$ signatures of $>60$ Kya likely attest continuity of the "short-bodied" populations indirectly, like the Munda, inhabiting the easternmost fringe of the Narmada Valley, who surprisingly, shares these signatures with the Andaman pygmy (Barik et al., 2008; Chandrasekar, 2009). Recent archaeological studies have demonstrated wide-spread and southeastward expansions of technologically Narmada-like Late Acheulian to Upper Palaeolithic and Mesolithic hominins (Sankhyan et al., 2011). Moreover, there is considerable anatomical gap between the NTK humerus and later Pleistocene ( $\sim 30$ Kya old) occupants of the Fa Hien cave of Sri Lanka (Kennedy \& Deraniyagala, 1989) and Darri-I-Kur of northeastern Afghanistan (Angel, 1972) which would continue to fuel debate on "Continuity" vs "Replacement".

\section{Acknowledgements}

The senior author, being the Principal Investigator of the Narmada Project sponsored by the Anthropological Survey of India Kolkata, thanks V. R. Rao, the then Director-in-Charge for facilities, and several notable experts, namely M. L. K. Murty, V. Shinde, S. R. Walimbe, Subrata Chakrabarti, and S. B. Ota, who examined the findings, as well as M. P. Tiwari and Yusuf Bhai to discuss Narmada stratigraphy during field operations.

\section{REFERENCES}

Acharyya, S. K., \& Basu, P. K. (1993). Toba ash on the Indian subcontinent and its implications for the correlation of Late Pleistocene Al- 
luvium. Quaternary Research, 40, 10-19.

doi:10.1006/qres.1993.1051

Angel, J. L. (1972). A middle Paleolithic temporal bone from Darra-iKur, Afghanistan. In L. Dupree (Ed.), Prehistoric research in Afghanistan (1959-1966). Transactions of American Philosophical Society, 62, 54-56.

Athreya, S. (2007). Was Homo heidelbergensis in South Asia? A test using the Narmada fossil from central India. In M. D. Petraglia, \& B. Allchin (Eds.), The evolution and history of human populations in South Asia (pp. 137-170). New York: Springer Press.

doi:10.1007/1-4020-5562-5 7

Badam, G. L., Ganjoo, R. K., Salahuddin, M., \& Rajaguru, S. N. (1986). Evaluation of fossil hominin-The maker of Late Acheulean tools at Hathnora, Madhya Pradesh, India. Current Science, 55, 143-145.

Badam, G. L., \& Sankhyan, A. R. (2009). Evolutionary trends in Narmada fossil fauna. In A. R. Sankhyan (Ed.), Asian perspectives on human evolution (pp. 92-102). New Delhi: Serials Publications.

Barik, S. S., Sahani, R., Prasad, B. V. R., Endicott, P. et al. (2008). Detailed mtDNA genotypes permit a reassessment of the settlement and population structure of the Andaman Islands. American Journal of Physical Anthropology, 136, 19-27. doi:10.1002/ajpa.20773

Bermudez de Castro J. M., Carretero, J. M., Garcia-Gonzalez R., Rodriguez-Garcia, L., Martinon-Torres, M., Rosell, J., Blasco, R., MartınFrances, L., Modesto, M., \& Carbonell, E. (2012). Early pleistocene human humeri from the gran dolina-TD6 site (Sierra de Atapuerca, Spain). American Journal of Physical Anthropology, 147, 604-617. doi:10.1002/ajpa. 22020

Cameron, D., Patnaik, R., \& Sahni, A. (2004). The phylogenetic significance of the Middle Pleistocene Narmada hominin cranium from central India. International Journal of Osteoarchaeology, 14, 419447. doi:10.1002/oa.725

Carretero, J. M., Haile-Selassie, Y., Rodríguez, R., \& Arsuaga, J. L. (2009). A partial distal humerus from the Middle Pleistocene deposits at Bodo, middle awash, Ethiopia. Anthropological Science, 117, 19-31. doi:10.1537/ase.070413

Chandrasekar, A., Kumar, S., Sreenath, J. et al. (2009). Updating phylogeny of mitochondrial DNA macrohaplogroup M in India: Dispersal of modern human in South Asian Corridor. PLOS ONE, 4, 1-13. doi:10.1371/journal.pone.0007447

Chesner, C. A., Rose, W. I., Drake, A. D. R., \& Westgate, J. A. (1991). Eruptive history of earth's largest quaternary caldera (Toba, Indonesia) clarified. Geology, 19, 200-203. doi:10.1130/0091-7613(1991)019<0200:EHOESL >2.3.CO;2

Churchill, S. E. (2007). Endocrine models of skeletal robusticity and the origins of gracility. In A. R. Sankhyan, \& V. R. Rao (Eds.), Human origins, genome and people of India (pp. 337-368). New Delhi: Allied Publishers.

Ganjoo, R. K., Rajaguru, S. N., \& Gupta, A. (1996). On the problem of age and genesis of Bhedaghat waterfalls (Jabalpur), Madhya Pradesh, Journal Geological Society of India, 48, 421-425.

Van Heteren, A. H., \& Sankhyan, A. R. (2009). Hobbits and pygmies: Trends in evolution. In A. R. Sankhyan (Ed.), Asian perspectives on human evolution (pp. 172-187). New Delhi: Serials Publications.

James, H. V. A., \& Petraglia, M. D. (2005). Modern human origins and the evolution of behavior in the later pleistocene record of South Asia. Current Anthropology, 46, 3-27. doi:10.1086/444365

Kennedy, K. A. R. (2000). God-apes and fossil men: The paleoanthropology of South Asia. Michigan: The University of Michigan Press.

Kennedy, K. A. R. (2007). The Narmada fossil hominid. In A. R. Sankhyan, \& V. R. Rao (Eds.), Human origins, genome and people of India (pp. 188-192). New Delhi: Allied Publishers.

Kennedy, K. A. R., \& Deraniyagala, S. U. (1989). Fossil remains of 28,000 year old hominids from Sri Lanka. Current Anthropology, 30, 394-399. doi: $10.1086 / 203757$

Kennedy, K. A. R., Sonakia, A., Chiment, J., \& Verma, K. K. (1991). Is the Narmada hominin an Indian Homo erectus? American Journal of Physical Anthropology, 86, 475-496. doi:10.1002/ajpa.1330860404

Khan, A., \& Sonakia, A. (1992). Quaternary deposits of Narmada with special reference to the hominid fossil. Journal of the Geological Society of India, 39, 147-154.

De Lumley, H., \& Sonakia, A. (1985). Contexte stratigraphique et
Archéologique de L'Homme de le Narmada, Hathnora, Madhya Pradesh, Inde. L'Anthropologie, 89, 3-12.

Lumley, M. A., \& Sonakia, A. (1985). Premiere Découverte D’un Homo erectus Sur Le Continent Indien a Hathnora, Dans la Moyenne vallée de la Narmada. L'Anthropologie, 89, 13-61.

Mallasse, A. D. (2009). Cranial embryogeny and hominin phylogeny. In A. R. Sankhyan (Ed.), Asian perspectives on human evolution (pp. 103-121). New Delhi: Serials Publications.

Oppenheimer, C. (2002). Limited global change due to largest known Quaternary eruption, Toba $\sim 74$ Kyr BP. Quaternary Science Review, 21, 1593-1609. doi:10.1016/S0277-3791(01)00154-8

Oppenheimer, C. (2003). Ice core and palaeoclimatic evidence for the great volcanic eruption of 1257. International Journal of Climatology, 23, 417-426. doi:10.1002/joc.891

Patnaik, R., Chauhan, P. R., Rao, M. R., Blackwell, B. A. B., Skinner, A. R., Sahni, A., Chauhan, M. S., \& Khan, H. S. (2009). New geochronological, paleoclimatological and Paleolithic data from the Narmada Valley hominin locality, Central India. Journal of Human Evolution, 56, 114-133. doi:10.1016/j.jhevol.2008.08.023

Pearson, O. M. (2000). Activity, climate and postcranial robusticity: Implications for modern human origins and scenarios of adaptive change. Current Anthropology, 41, 569-605. doi:10.1086/317382

Petraglia, M. D., \& Alsharekh, A. (2003). The middle paleolithic of Arabia: Implications for modern human origins, behaviour and dispersals. Research (Online).

Petraglia, M. D. (2007). Middle paleolithic assemblages from the Indian Subcontinent before and after the Toba Super-Eruption. Science, 317, 114-116. doi:10.1126/science.1141564

Rose, W. I., \& Chesner, C. A. (1990). Worldwide dispersal of ash and gases from earth's largest known eruption: Toba, Sumatra, $75 \mathrm{Ka}$. Palaeogeography, Palaeo-Climatology, Palaeoecology, 89, 269-275. doi:10.1016/0031-0182(90)90068-I

Sankhyan, A. R. (1997a). Fossil clavicle of a Middle Pleistocene hominid from the Central Narmada Valley, India. Journal of Human Evolution, 32, 3-16. doi:10.1006/jhev.1996.0117

Sankhyan, A. R. (1997b). A new human fossil find from the Central Narmada basin and its chronology. Current Science, 73, 1110-1111.

Sankhyan, A. R. (2005). New fossils of Early Stone Age man from Central Narmada Valley. Current Science, 88, 704-707.

Sankhyan, A. R. (1999). The place of Narmada hominin in the Jigsaw puzzle of human origins. Gondwana Geological Magazine Special Publication, 4, 335-345.

Sankhyan, A. R. (2006). On the status of Indian hominoid and hominid fossils. In R. Ray, \& V. Jayaswal (Eds.), Status of Prehistoric Studies in the 21st Century in India, Proceedings of 15th UISPP Congress, Lisbon, BAR International Series 1924 (pp. 13-23), Oxford: Archaeo Press.

Sankhyan, A. R. (2010). Pleistocene Hominins \& associated findings from central Narmada Valley bearing on the evolution of man in South Asia. Ph.D. Thesis, Chandigarh: Panjab University.

Sankhyan, A. R. \& Rao, V. R. (2007). Did ancestors of the Pygmy or Hobbit ever live in Indian heartland? In E. Indriati (Ed.), Recent advances on Southeast Asian paleoanthropology and archeology (pp. 76-89). Yogyakarta: Gadjah Mada University.

Sankhyan, A. R., Dewangan, L. N., Sahoo, R. H., Chakravarty, R., \& Chatterjee, R. (2011). Early prehistoric signatures of man in Bastar region, Central India. Current Science, 101, 1146-1149.

Sonakia, A. (1984). The skullcap of Early Man and associated mammalian fauna from Narmada Valley Alluvium, Hoshangabad area, M.P. (India). Records Geological Survey of India, 113, 159-172.

Tiwari, M. P., \& Bhai H. Y. (1997). Quaternary stratigraphy of the Narmada Valley. Geological Survey of India Special Publication, 46, 33-63.

Todd, R. Y., \& Churchill, S. E. (2006). Archaic and modern human distal humeral morphology. Journal of Human Evolution, 51, 603616. doi:10.1016/j.jhevol.2006.07.006

Trinkaus, E. (2007). Appendicular robusticity and the paleobiology of modern human emergence. Proceedings of the National Academy of Sciences of the United States of America, 94, 13367-13373. doi:10.1073/pnas.94.24.13367

Trinkaus, E., \& Ruff, C. B. (1999). Diaphyseal cross-sectional Geome- 


\section{A. R. SANKHYAN ET AL.}

try of Near Eastern Middle Palaeolithic Humans: The Femur. Journal Archaeological Science, 26, 409-424.

doi:10.1006/jasc.1998.0343

Weaver, T. D. (2009). The meaning of Neandertal skeletal morphology. Proceedings of the National Academy of Sciences of the United States of America, 106, 6028-16033. doi:10.1073/pnas.0903864106
Westgate, J. A., Shane, P. A. R., Pearce, N. J. C., Perkins, W. T., Korisettar, R., Chesner, C. A., Williams, M. A. J., \& Acharyya, S. K. (1998). All Toba tephra occurrences across Peninsular India belong to 75,000 years B.P. Eruptions. Quaternary Research, 50, 107-112. doi:10.1006/qres.1998.1974 